\title{
Peranan Teknologi Dan Informasi Dalam Kepemimpinan Di Karang Taruna Kelurahan Harapan Jaya
}

\author{
Jumawan ${ }^{1,{ }^{*}, \text { Hadita }}{ }^{1}$, Rakhmi Khalida ${ }^{1}$ \\ ${ }_{1}^{1}$ Fakultas Teknik, Universitas Bhayangkara Jakarta Raya; Jl. Raya Perjuangan, Marga Mulya, \\ Bekasi Utara, Jawa Barat 17121. Telp: 021-88955882, 889955883, e-mail: \\ jumawan@dsn.ubharajaya.ac.id; e-mail: hadita.universitas@gmail.com; e-mail: \\ rakhmi.khalida@dsn.ubharajaya.ac.id \\ * Korespondensi: e-mail: jumawan@dsn.ubharajaya.ac.id
}

\begin{abstract}
Devotion to the community is one of the mandatory activities that must be implemented by a lecturer as part of Three duties college, which aims to implement and implement the scientific competence that is owned to contribute positively to the needs of the community. Community service activities carried out in Karang Taruna RW.18 Harapan Jaya Subdistrict, North Bekasi Subdistrict West Java Province is a manifestation of the creativity of lecturers and students who want to provide knowledge in the field of information technology and leadership. Because many people, especially young people who lack knowledge that the importance of technology and information needs in the leadership of an organization. The material given in the training of technology and information role in leadership in Karang Taruna RW.18 Harapan Jaya urban village is a socialization, understanding of technology and information needs in leadership in an organization or company. The expected objectives after this training are the young generation in Karang Taruna RW.18 Harapan Jaya urban village can add and apply technology and information on the leadership of an organization or company to achieve the goals of the organization or company.
\end{abstract}

Keywords: Technology and Information, Leadership, Organization.

\begin{abstract}
Abstrak
Pengabdian kepada masyarakat merupakan salah satu kegiatan wajib yang harus dilaksanakan oleh seorang dosen sebagai bagian dari tri dharma perguruan tinggi yang bertujuan untuk menerapkan dan mengimplementasikan kompetensi keilmuan yang dimiliki guna memberikan kontribusi positif bagi kebutuhan masyarakat. Kegiatan pengabdian masyarakat yang dilaksanakan di Karang Taruna RW.18 Kelurahan Harapan Jaya Kecamatan Bekasi Utara Provinsi Jawa Barat merupakan perwujudan kreativitas dosen dan mahasiswa yang ingin memberikan pengetahuanya di bidang teknologi informasi dan kepemimpinan. Oleh karena banyak diantara masyarakat, khususnya para pemuda-pemudi yang kurang memiliki pengetahuan bahwa betapa pentingnya kebutuhan teknologi dan informasi dalam kepemimpinan suatu organisasi. Materi yang diberikan pada pelatihan peranan teknologi dan informasi dalam kepemimpinan di Karang Taruna RW.18 Kelurahan Harapan Jaya yaitu sosialisasi pemahaman kebutuhan teknologi dan informasi dalam kepemimpinan di suatu organisasi ataupun perusahaan. Tujuan yang diharapkan setelah pelatihan ini para generasi muda di Karang Taruna RW.18 Kelurahan Harapan Jaya dapat menambah dan mengaplikasikan teknologi dan informasi dalam kepemimpinan suatu organisasi atau perusahaan untuk mencapai tujuan organisasi atau perusahaan tersebut.
\end{abstract}

Kata Kunci: Teknologi dan Informasi, Kepemimpinan, Organisasi. 


\section{Pendahuluan}

Program pengabdian bertema peran teknologi dan informasi dalam kepemimpinan merupakan salah satu program utama tri dharma Universitas Bhayangkara Jakarta Raya yang bertujuan mendukung dan membantu mewujudkan cita-cita masyarakat, terutama dengan memberikan pengetahuan yang berkaitan dengan teknologi informasi dan kepemimpinan. Kegiatan ini dilaksanakan berdasarkan berbagai cabang ilmu. Dalam pelaksanaannya, tema kegiatan dilaksanankan dalam bentuk sosialisasi pemahaman kebutuhan teknologi dan informasi dalam kepemimpinan di suatu organisasi ataupun perusahaan (Sedarmayanti, 2014). Kegiatan tersebut bertujuan untuk meningkatkan penguasaan ilmu pengetahuan dan jiwa kepemimpinan bagi mahasiswa dan masyarakat luas. Karang taruna adalah suatu organisasi sosial, perkumpulan sosial yang dibentuk oleh masyarakat yang berfungsi sebagai sarana partisipasi masyarakat dalam melaksanakan Usaha Kesejahteraan Sosial (UKS). Sebagai wadah pengembangan generasi muda, karang taruna merupakan tempat diselenggarakannya berbagai upaya atau kegiatan untuk meningkatkan dan mengembangkan cipta, rasa, karsa, dan karya generasi muda dalam rangka pengembangan sumber daya manusia (SDM). (Hasibuan, 2011).

Menurut fakta dilapangan pemuda pemudi karang taruna RW. 18 yang berlokasi di Kelurahan Harapan Jaya Bekasi-Utara, sudah memiliki usaha namun terkendala dalam hal memimpin supaya usahanya bisa maju dan berkembang. Dihadapkan pada perkembangan teknologi informasi (TI) sekarang ini, meskipun banyak masyarakat yang sudah familiar dengan teknologi informasi yang semakin mudah digunakan dan harga yang murah tetapi banyak generasi muda dari karang taruna ini masih kurang pengetahuannya dalam hal teknologi informasi yang dikaitkan dengan kepemimpinan.

Untuk memajukan organisasi, karang taruna ini harus mengerti perpaduan teknologi dan sistem informasi dengan aspek-aspek manajemen lainnya agar dapat memberikan dukungan maksimal terhadap pencapaian tujuan organisasi (Muhajirin, et al, 2018). Organisasi perlu melakukan penggalian sumber daya manusia dan sumber daya Teknologi Informasi (TI) hingga diperoleh suatu peluang yang dapat dimanfaatkan dan dikembangkan oleh para pelaku yang terlibat dalam organisasi (Zainuddin, 2018).

Semua itu dimanfaatkan untuk menjawab laju pesat perkembangan budaya yang memiliki spirit terhadap teknologi (Wijaya \& Iwan, 2015). Ada beberapa konsep pemikiran teknologi dan informasi dalam kepemimpinan yang sering menjadi dasar selama ini antara lain konsep pada materi perencanaan strategis teknologi informasi $(\mathrm{TI})$ dan manajemen proyek teknologi informasi $(\mathrm{TI})$. Konsep tersebut terdiri atas metode-metode yang diurutkan secara logis dan memiliki kelebihan satu dengan yang lainnya. Sebagaimana peran pemimpin yang terlibat dalam seluruh tahap penanganan informasi, oleh karena itu peran teknologi informasi sudah tidak dapat dipisahkan lagi dalam kepemimpinan (Suwandi, 2016). Konsep pemikiran teknologi dan informasi dalam kepemimpinan menciptakan sebuah perancangan sistem informasi yang sesuai dengan kebutuhan organisasi. (Robert \& Peter, 2008). Pelatihan 
kepemimpinan yang dikaitkan dengan peran teknologi dan informasi diharapkan dapat menciptakan pemimpin yang unggul kompetitif dalam globalisasi, pemimpin yang bertanggung jawab atas perencanaan, penyelarasan, penyiapan, implementasi, dan evaluasi teknologi informasi dan komunikasi (TIK) di dalam suatu organisasi, pemimpin teladan mengayomi yang dipimpin, pemimpin yang bertanggung jawab, pemimpin yang memikirkan regenerasi para generasi muda. (Handoko, 2011). Karang Taruna RW.18 nantinya dapat memanfaatkan dan mengaplikasikan pengetahuan dan wawasan yang didapat di organisasi ataupun perusahaan tempat mereka berada. Berdasarkan latar belakang yang sudah penulis selaku dosen fakultas ekonomi, prodi manajemen dan tim pelaksana pengabdian masyarakat mengangkat judul mengenai : "Peranan Teknologi dan Informasi dalam Kepemimpinan di Karang Taruna RW 18 Kelurahan Harapan Jaya Kecamatan Bekasi Utara Provinsi Jawa Barat".

\section{Tujuan Kegiatan}

Tujuan dari kegiatan pengabdian kepada masyarakat yang diselenggarakan oleh Prodi Manajemen, Fakultas Ekonomi. Universitas Bhayangkara Jakarta Raya ini adalah: 1). Membuka pengetahuan dan wawasan bagi para karang taruna dalam meningkatkan pengetahuan dan wawasan dalam hal kemajuan teknologi dan informasi sehingga nantinya para generasi muda mampu bersaing di bidang teknologi informasi dalam mencapai tujuan organisasi ataupun tujuan perusahaan tersebut. 2). Memberikan pelatihan tentang kepemimpinan yang efektif di suatu organisasi atau perusahaan sehingga tercapai semua tujuan organisasi atau perusahaan tersebut. 3). Memfasilitasi dan memperluas peluang bagi dosen untuk menyelenggarakan pengabdian masyarakat sebagai wujud pengimplementasian dari tri dharma perguruan tinggi yang merupakan bentuk pengabdian kami kepada masyarakat khususnya dalam hal peran teknologi dan informasi dalam kepemimpinan kepada para generasi muda di karang taruna RW. 18 Kelurahan Harapan Jaya.

\section{Mitra Kegiatan}

Mitra kegiatan pengabdian pada masyarakat adalah Karang taruna Rw.18 Kelurahan Harapan Jaya Kecamatan Bekasi Utara Provinsi Jawa Barat. Berdiri pada tahun 2005 dengan pergantian kepemimpinan selama 5 tahun, pada tahun 2015 karang taruna ini dipimpin oleh Bp.Mohammad Ridho selaku ketua karang taruna dengan masa bhakti berakhir pada tahun 2020 dibawah pengawasan Bp. Effendi selaku ketua RW setempat yang beranggotakan lebih dari 26 orang. Menurut fakta dilapangan pemuda pemudi karang taruna RW. 18 yang berlokasi di Kelurahan Harapan Jaya Bekasi-Utara, sudah memiliki usaha namun terkendala dalam hal memimpin supaya usahanya bisa maju dan berkembang. Dihadapkan pada perkembangan teknologi informasi (TI) sekarang ini, meskipun banyak masyarakat yang sudah familiar dengan teknologi informasi yang semakin mudah digunakan dan harga yang murah tetapi banyak generasi muda dari karang taruna ini masih kurang pengetahuannya dalam hal teknologi informasi yang dikaitkan dengan kepemimpinan. Untuk memajukan organisasi, karang taruna ini harus mengerti perpaduan teknologi dan sistem informasi dengan aspek-aspek manajemen lainnya agar dapat memberikan dukungan maksimal terhadap pencapaian tujuan organisasi. 
Pelatihan kepemimpinan yang dikaitkan dengan peran teknologi dan informasi diharapkan dapat menciptakan pemimpin yang efektif, pemimpin teladan mengayomi yang dipimpin, pemimpin yang bertanggung jawab, pemimpin yang memikirkan regenerasi para generasi muda, Karang Taruna RW.18 nantinya dapat memanfaatkan dan mengaplikasikan pengetahuan dan wawasan yang didapat di organisasi ataupun perusahaan tempat mereka berada.

\section{Persoalan Mitra}

Berdasarkan rumusan masalah yang telah diuraikan diharapkan dapat menghasilkan suatu luaran sebagai berikut: 1). Membuka pengetahuan dan wawasan ilmu dan pengetahuan tentang bagaimana memanfaatkan dan menggunakan teknologi dan informasi dalam kepemimpinan sehingga mampu menghadapi persaingan di era sekarang ini. 2). Memberikan pelatihan peran teknologi dan informasi dalam kepemimpinan di Karang Taruna RW. 18. 3). Membantu merealisasikan teknologi dan informasi dalam kepemimpinan efektif dengan menuangkan ke dalam langkah konkrit implementasi, sehingga mereka akan berupaya untuk patuh dan disiplin mengikuti langkah- langkah yang sudah ditetapkan dalam hal tersebut. 4). Menerapkan dan menyebarluaskan hasil-hasil pengabdian masyarakat dalam bentuk jurnal, buku bahan ajar dan modul pelatihan kepada masyarakat sebagai bagian dari upaya untuk memberdayakan dan meningkatkan kualitas hidup masyarakat.

\section{Lokasi dan Status Sosial Mitra}

Lokasi mitra terletak di jalan PLN Harapan Jaya Bekasi Utara yang berjarak kurang lebih $20 \mathrm{~km}$ dari lokasi Universitas Bhayangkara Jakarta Raya kampus II (Bekasi). Lokasi tersebut dapat ditempuh dengan sarana transportasi seperti angkutan umum, kendaraan pribadi seperti mobil dan motor. Status sosial mitra adalah para pegawai, mahasiswa dan ibu rumah tangga dan pedagang.

\section{TARGET LUARAN}

Target luaran yang akan dihasilkan dari pelatihan peran teknologi dan informasi dalam kepemimpinan di Karang Taruna RW 18 Kelurahan Harapan Jaya adalah dapat mewujudkan kualitas hidup yang lebih baik: 1). Membuka pengetahuan dan wawasan ilmu dan pengetahuan tentang bagaimana memanfaatkan dan menggunakan teknologi dan informasi dalam kepemimpinan sehingga mampu menghadapi persaingan di era sekarang ini. 3). Memberikan pelatihan peran teknologi dan informasi dalam kepemimpinan di Karang Taruna RW. 18. 3). Membantu merealisasikan teknologi dan informasi dalam kepemimpinan efektif dengan menuangkan ke dalam langkah konkrit implementasi, sehingga mereka akan berupaya untuk patuh dan disiplin mengikuti langkah - langkah yang sudah ditetapkan dalam hal tersebut. 4). Menerapkan dan menyebarluaskan hasil-hasil pengabdian masyarakat dalam bentuk jurnal, buku bahan ajar dan modul pelatihan kepada masyarakat sebagai bagian dari upaya untuk memberdayakan dan meningkatkan kualitas hidup masyarakat. 


\section{Metode Pelaksanaan}

Kegiatan yang dilaksanakan berupa pelatihan sosialisasi teknologi informasi dalam kepemimpinan. Materi pelatihan disesuaikan dengan kebutuhan masyarakat di karang taruna RW 18 Harapan Jaya. Pada tahap persiapan, tim pengabian ini melaksanakan beberapa kegiatan, diantaranya survey lokasi, perizinan dan sosialisasi. Langkah berikutnya adalah persiapan lokasi dan persiapan modul pelatihan serta peralatan pendukung dan langkah berikutnya adalah pelaksanaan. Terwujudnya pengabdian masyarakat di karang taruna RW 18 Harapan Jaya merupakan bukti keberhasilan disiplin berbagai cabang ilmu. Untuk mengukur tingkat keberhasilan kegiatan pengabdian ini, peserta diberikan kuesioner pre-test (sebelum) pelatihan dan kuesioner post-test (sesudah) pelatihan dalam bentuk kuesioner yang berisi tes pengujian kemampuan teknologi informasi dan kepemimpinan. Tahap ini dimaksudkan untuk mengetahui kemampuan peserta dalam hal teknologi informasi dan kepemimpinan para peserta pelatihan. Berdasarkan jawaban pre-test dan post-test terlihat perubahan kemampuan peserta sebelum dan sesudah mengikuti pelatihan. Tingkat keberhasilan tersebut dapat dilihat dari ketertarikan masyarakat dalam mengikuti seluruh kegiatan pengabdian masyarakat dan harapan dari masyarakat bahwa kegiatan ini dapat terus dilanjutkan dengan tema-tema inovatif dan ilmu terbarukan di karang taruna RW 18 Harapan Jaya. Alur kegiatan pengabdian kepada masyarakat ditunjukan pada gambar berikut:

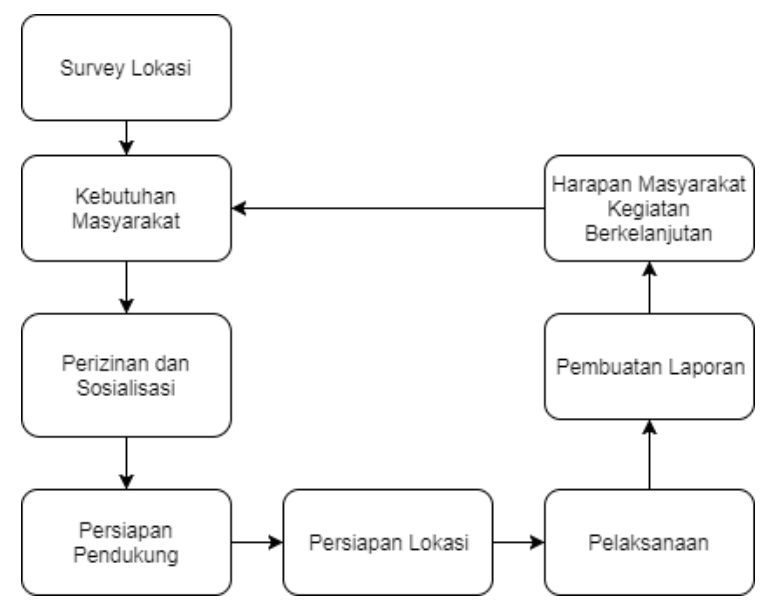

Sumber: Hasil Penelitian (2020)

Gambar 1. Metode Pelaksanaan Pengabdian Masyarakat

\section{Hasil dan Pembahasan}

Pelaksanaan pelatihan dalam rangka pengabdian kepada masyarakat dilaksanakan di karang taruna RW 18 Harapan Jaya pada tanggal 13 dan 14 Januari 2018 yang berlangsung pada pukul 08.30 sd 13.00. Narasumber terdiri dari tiga orang dosen yang dibantu dengan 3 mahasiswa sebagai panitia sekaligus asisten pelatihan. 


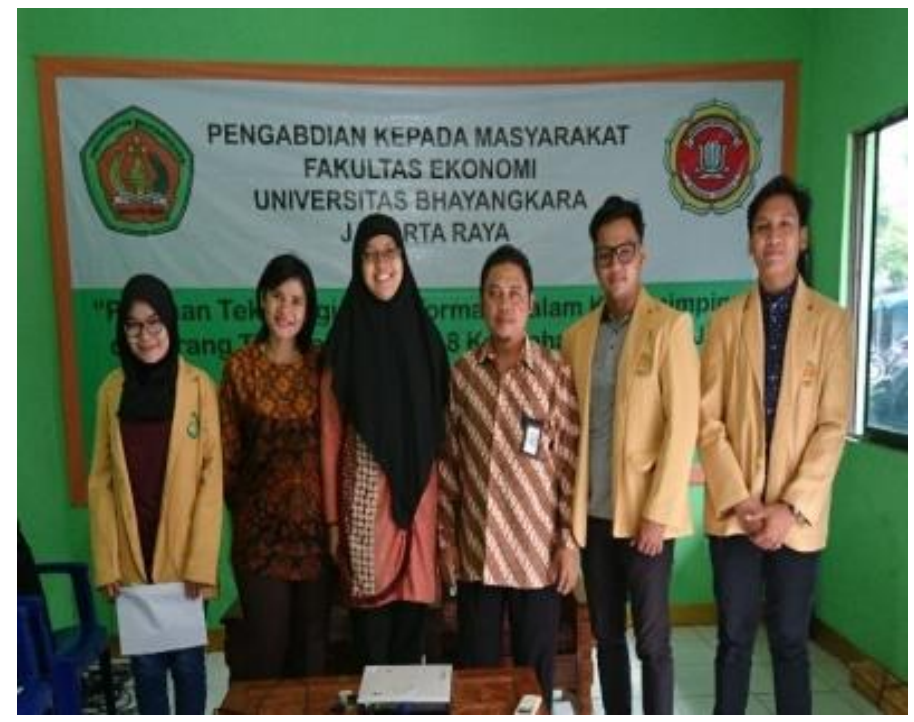

Sumber: Hasil Pelaksanaan (2020)

Gambar 2. Tim Pengabdian Kepada Masyarakat UBJ di Karang Taruna RW 18 Harapan Jaya

Jumlah peserta secara keseluruhan adalah 30 peserta yang terdiri dari anggota karang taruna kelurahan dan anggota Karang Taruna RW 18 Kelurahan Harapan Jaya serta masyarakat sekitar RW 18. Kegiatan - kegiatan yang telah dilakukan dapat dari beberapa dokumentasi yang dirangkum berikut ini.

Jumlah peserta secara keseluruhan adalah 30 peserta yang terdiri dari anggota karang taruna kelurahan dan anggota karang taruna RW 18 Kelurahan Harapan Jaya serta masyarakat sekitar RW 18. Kegiatan - kegiatan yang telah dilakukan dapat dari beberapa dokumentasi yang dirangkum berikut ini.

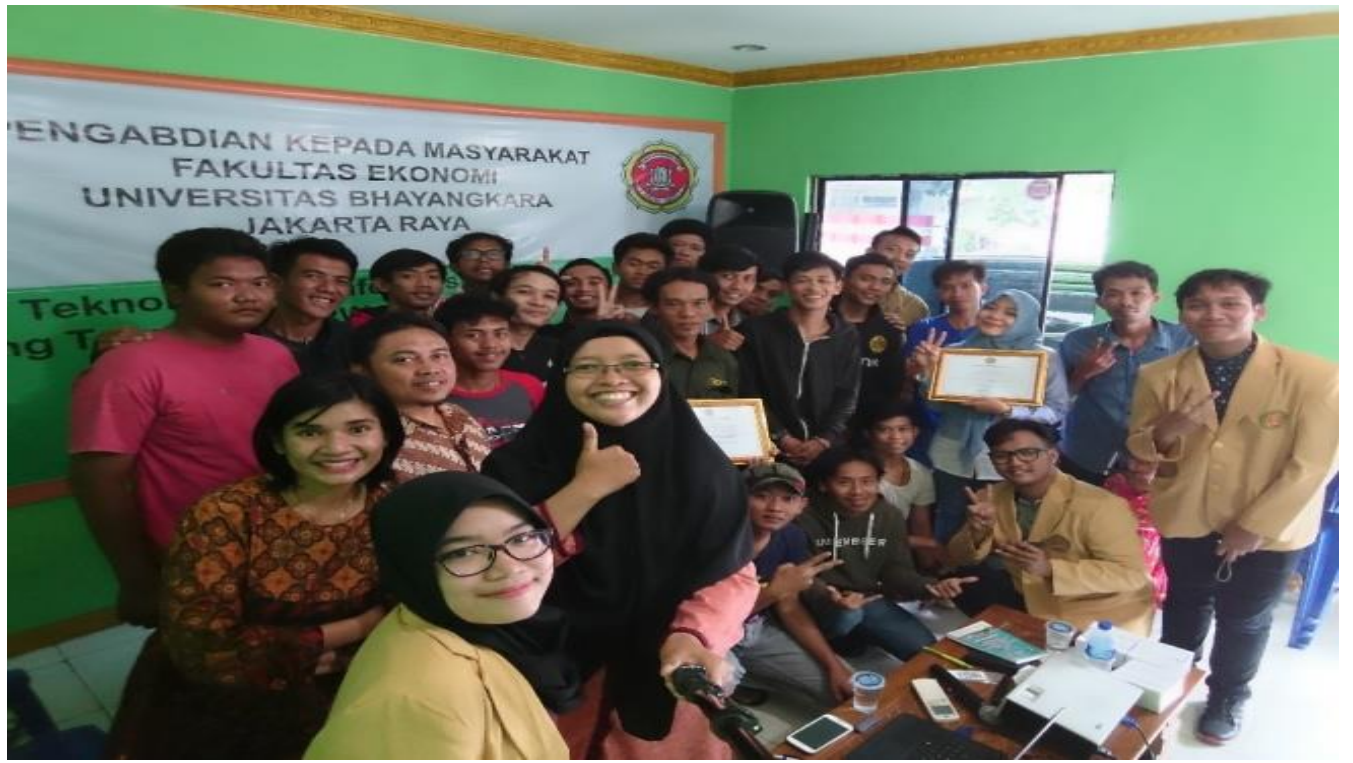

Sumber: Hasil Pelaksanaan (2020)

Gambar 3: Pelaksanaan Pengabdian Kepada Masyarakat di Karang Taruna RW 18 Harapan Jaya 
Peserta pelatihan sangat antusias dapat dilihat dari diskusi yang dilakukan selama kegiatan berlangsung. Dari pretes dan postes yang sudah dilaksanakan oleh peserta pelatihan, diperoleh hasil nilai rata - rata pretes dari 30 peserta adalah 70,8 sedangkan nilai rata-rata postes mencapai 93,2. Dari nilai rata-rata pretes dan postes memperlihatkan terjadinya peningkatan nilai sebesar 22,4. Hal ini menunjukkan bahwa pelatihan memberikan tambahan pengetahuan mengenai teknologi dan informasi yang berperan dalam kepemimpinan dan memberikan pemahaman kepada peserta tentang pemimpin yang unggul kompetitif tetapi juga teladan.

Arahan dan bimbingan yang diberikan meningkatkan pengetahuan para peserta, hal ini dapat dilihat dari rata-rata nilai pretest dan posttest yang peserta kerjakan.

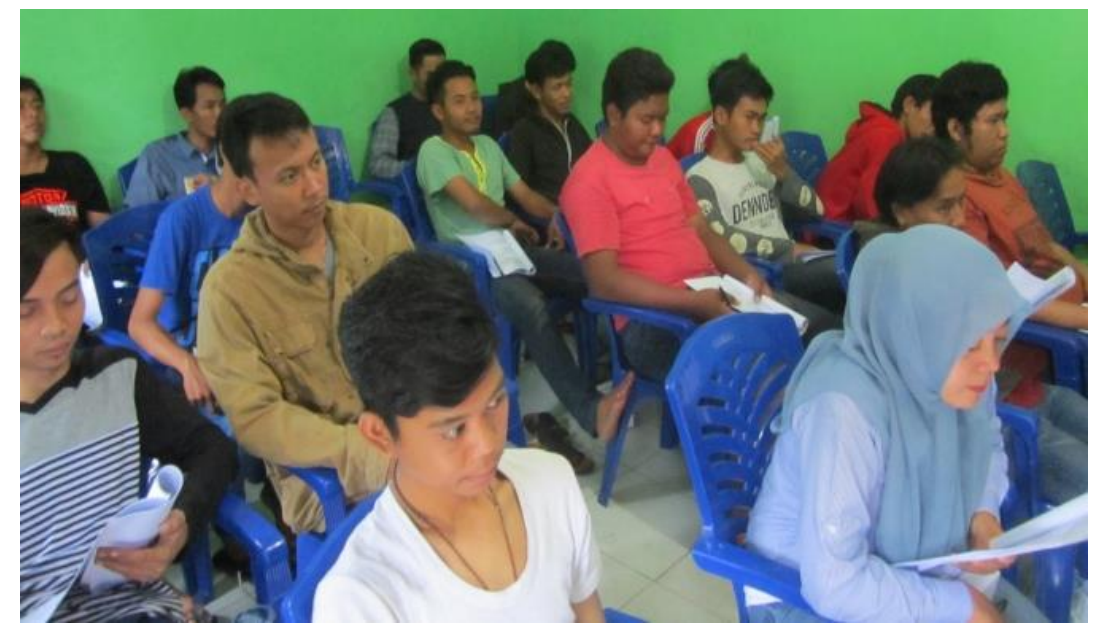

Sumber: Hasil Pelaksanaan (2020)

Gambar 4. Antusiasme Peserta Pelatihan Pengabdian Kepada Masyarakat di Karang Taruna RW 18 Harapan Jaya

Indikasi tingkat keberhasilan kegiatan pengabdian kepada masyarakat ini didasarkan kepada ketertarikan masyarakat dalam mengikuti seluruh kegiatan pengabdian masyarakat dan harapan dari masyarakat bahwa kegiatan ini dapat terus dilanjutkan dengan tema-tema inovatif dan ilmu terbarukan.

\section{Kesimpulan}

Berdasarkan hasil pelaksanaan kegiatan pengabdian kepada masyarakat yang telah dilakukan, dapat diambil kesimpulan sebagai berikut: 1). Kegiatan pengabdian kepada masyarakat mengenai pelatihan peranan teknologi dan informasi dalam kepemimpinan di karang taruna Rw.18 Kelurahan Harapan Jaya Kecamatan Bekasi Utara Provinsi Jawa Barat berjalan lancar dan memperoleh sambutan positif dari warga setempat. 2). Penyaji pelatihan dapat memberikan wawasan tentang peranan teknologi dan informasi dalam kepemimpinan di suatu oragnisasi atau perusahaan serta dapat saling berdiskusi tentang sistem tata kelola manajemen didalam karang taruna itu sendiri. Berdasarkan pelatihan pengabdian kepada 
masyarakat yang telah dilakukan maka disarankan: 1). Keterlibatan pemimpin atau pejabat setempat untuk ikut andil didalam memberikan pengarahan dan memantau aktivitas anggota karang taruna sebagai kegiatan yang positif. 2). Diperlukan pelatihan-pelatihan yang lain untuk menambah skill dan wawasan bagi karang taruna sebagai nilai tambah untuk meningkatkan kontribusi.

\section{Ucapan Terima Kasih}

Penulis mengucapkan terima kasih sebesar-besarnya kepada para peserta yang terdiri dari sosial mitra adalah para pegawai, mahasiswa dan ibu rumah tangga dan pedagang di Karang Taruna RW 18 Harapan Jaya.

\section{Daftar Pustaka}

Muhajirin, A., Yusuf, D, Mukhlis., Handayani, D, \& Lestari, T.S. (2018). Pelatihan Penyimpanan Digital Siswa Sebagai Sarana Mendukung Gerakan Green ICT SMA Dan SMK Gala Juara Bekasi Utara: Jurnal Pengabdian Kepada Masyarakat Universitas Bhayangkara Jakarta Raya.

Handoko, T.H. (2011). Manajemen Personalia dan Manajemen Sumber Daya Manusia. BPFE, Yogyakarta.

Hasibuan, M. (2011). Manajemen Sumber Daya Manusia, Yogyakarta: Graha Ilmu.

Hisrich., R.D., Peters \& Michael P. (2008). Entrepreneurship Kewirausahaan (7th ed). Jakarta: Salemba Empat.

Zainuddin, M, Syamsudin, A \& Yahya, M.R.. (2018). Peningkatan Eksistensi Organisasi Siswa Intra Sekolah (OSIS) Se Kota Pekanbaru Melalui Konsep Manajemen dan Kepemimpinan: Jurnal Pengabdian Kepada Masyarakat.

Sedarmayanti. (2014). Kepemimpinan. Yogyakarta: Graha IImu.

Suwandi. (2012). Perencanaan Strategis Informasi. http://blog.pasca.gunadarma.ac.id/2012/07/21/perencanaan-strategis-sistem-informasi. Diakses tanggal 20 September 2017

Wijaya, I.K. (2015). Manajemen Proyek Teknologi Informasi. Yogyakarta: Grahallmu. 